\title{
Some Factor Affecting the Trend of Aggressive Behavior of Adolescents in the Tourist Areas in Kuta Bali
}

\author{
I Wayan Susanta \\ \{wayansusanta1961@gmail.com\} \\ IKIP PGRI Denpasar, Bali, Indonesia
}

\begin{abstract}
The purpose of this study is to determine the effect of peer group interaction, and the interaction of adolescents with tourists on the tendency of aggressive behavior of adolescents in Bali's tourist areas. By using the stratified random sampling technique, the examined sample had as many as 180 people. Data were collected through questionnaires. The data were analyzed using the multiple correlation analysis. The results showed that the interaction of peer groups and the interaction of adolescents with tourists significantly influenced the tendency of aggressive behavior, which means that the variations in the tendency of aggressive behavior were caused by peer group interaction and by the interaction of adolescents with tourists.
\end{abstract}

Keywords: peer group interaction, adolescent interaction with tourists, adolescent aggressive behavioral tendency.

\section{Introduction}

Aggression can typically be defined as any form of behavior intended to harm a person against their will. Aggression includes all forms of psychological or emotional torture[1].

Aggressive naturalistic behavior is all around us, not just in reality, but also in the entertainment that we enjoy all day. A film that features elements of violence such as the Rambo films where Sylvester Stallone's character earned the distinction of being a legendary character, can be a reinforcement for the audience. The show included injured body parts, mutilation news, and various sports that display elements of violence. All these will accumulatively form the seeds of aggression among the audience and especially among teenagers.

Aggressive behavior can cause physical and psychological injuries, can hurt social and personal integrity, as well as damage objects and social environment. Furthermore, aggressive behavior is explained not only to include aspects of physical actions, but also to include verbal violence aimed to harm others, psychological and symbolic violence, or a combination of all these aspects. Verbal abuse such as humiliation and threats, psychological violence such as attitudes that deny equality of rights and humanity, and symbolic violence are actions that generate fear and hostility.

The above description illustrates that aggressive behavior is a violent act both verbally and physically, deliberately committed by an individual or a group against another person or other objects in order to physically and psychologically harm them. Aggressive behavior does 
not only occur in developing countries like Indonesia alone but occurs worldwide in every segment of society. Print and electronic media report murders, robberies, thefts, and rapes almost every day. Aggressive behavior among adolescents appears in adolescent fights, logging, and violent acts involving teenagers, such as motorcycle gang violence in various areas such as Medan, Jakarta, Bandung, and other areas. In Denpasar-Bali, especially in the area of Sesetan, south of Denpasar, there was mistreatment of teenage girls by a gang of young women[2].

Peer group interaction is considered as a free variable. According to Santrock, aggression is more often done by a group. Circumstances that can trigger individuals also include groups. Given the spread of responsibility and polarization action, group conditions reinforce aggressive reactions[3].

Similarly, the Human Development book described the positive effect of peer group interaction saying that it helps children learn how to live together in society, how to adjust their desires and wishes to the ones of others, and when to be loud and when to stand still. However, the negative impact is the existence of destructive and antisocial behavior, and the susceptibility to pressure to imitate. This pressure can turn a recalcitrant child into a criminal[4].

Research findings indicate that peer interactions have a certain impact on personality development. Children who have high-quality friendships may not have a higher overall level of trust, but they have more positive social relationships with their peers. On the other hand, children with low-quality friendships with lots of quarrels and conflicts appear to develop a style of dissident and antagonistic behavior[5].

Furthermore, Roizatul Hasanah examined the pattern of association of teenagers in the National Park Alas Purwo Banyuwangi (Studies in adolescents hamlet ketorejo, Village Kalipahit, District Tegaldlimo, Banyuwangi) and found adolescents that interact with foreign tourists and practice English and teenagers who become guides for foreign tourists[6].

Irianto, faculty STIE AMM Mataram which examined "The impact of tourism on the social and economic life of society in Gili Trawangan sub-district winner Lombok District North", explains the findings that the impact of tourism led to the erosion of cultural values of local communities because local residents tend to imitate the lifestyle of foreign tourists. This interaction is mainly done by teenagers and will be repetitive. With its continuation, it is possible this interaction will be able to affect other aspects of the life of the adolescents, potentially leading to drug abuse, criminal action, and other destructive acts[7].

On the basis of the above two research findings, it can be concluded that the interaction of adolescents with sustainable tourists provides a tendency for adolescents to become immoral, abuse drugs, and engage themselves in other destructive actions in addition to the decline of the local cultural values. The exposure of research findings as the ones above that proves that the interaction of adolescents with tourists empirically led to the tendency of aggressive behavior in adolescents is worthy of being a free variable in its function as a predictor for the formation of aggressive behavior tendencies.

On the basis of the empirical studies described above, this study focuses on the research direction of the essentials as the main factor that is the possibility of a relationship between peers (peer group) and the aggressiveness of adolescents and the relationship between the interaction of adolescents with tourists and the aggressiveness of adolescents.

Bali is currently seen as a tourist area and there seems to have been social interaction between various cultures and ethnics as well as tourists, service vendors, hawkers, and local communities, especially teenagers. The process of interaction causes the process of culture obtained through the imitation process. This process takes place in an unconditioned situation. 
Unconditioned situations can cause teenagers to fall prey to destructive or immoral actions, especially aggressive behavior. This is consistent with the theory of differential association which states that "juvenile delinquency is the result of miscommunication"[8]. In conjunction with the above background, and to look at it further, the setting of this study includes the teenagers in the tourist area of Kuta Bali.

Behavior-related issues can reach complex and deep things. By the existence of various limitations, this research wants to touch on the following problems as follows: (1) does the peer group interaction affect the tendency of aggressive behavior of adolescents in Bali province? and (2) whether the interaction of adolescents with tourists influences the tendency of aggressive behavior of adolescents in Bali province.

The results of this study are expected to be useful or provide a positive contribution to the development of science education, psychology, and sociology, especially as a reference for the implementation of relevant studies. In addition to the theoretical benefits, the results of this study are expected to contribute to parents, teachers, the government, and formal and nonformal education institutions to condition influential factors, in the development of education and behavioral development for youth in the province of Bali.

\section{Research Methodology}

This research is classified as an "ex post facto" research. The study was conducted in January 2016. Samples were taken based on the technique of purposive sampling. The number of research samples included as many as 160 people determined based on data analysis unit used is multiple regression analysis[9]. Data on aggressive behavioral trends, peer group interactions, and teenage interactions with travelers were collected by questionnaire. The datasets of this research can be accessed from https://osf.io/5q2ke/ from the Open Science Frameworks.

\section{Research Findings and Discussions}

The first findings in this study found the interaction of peer group (X2) has a direct negative effect on the tendency of aggressive behavior (Y) of $48.6 \%$ in adolescents in Bali's tourist areas. This means that variations in aggressive behavior tendencies are caused by peer group interactions. In line with the findings of this study, that aggressive behavior is caused by group influence[10]. Similarly, aggressive behavior is also caused by conflicts between peers and are generated by competition, provocation, and misunderstandings among those who lead to avoid friends, are hardcore, and fight[11].

Peer group interaction is focused on achieving group and personal goals. In groups like these, teens get life satisfaction, social rewards, and the achievement of various desires. In such a group, teenagers learn to recognize the differences and bring together the commonalities of things. Furthermore, there is the development of social solidarity and a sense of solidarity towards the group begins to grow. Apart from these positive contributions, there are also excessive conformities that are militant, so that sometimes the objectivity of the group becomes neglected in some cases because the group activities are not well organized and the activities are often temporary and dynamic, so often aggressive actions such as mutual abuse, fights, and brawl appear on a large scale. This is in line with the research conducted by Rina 
who stated in the Health Journal of Prima Vol. 3 July 2, 2011, that aggressive behavior is backed by external factors in the form of ridicule from friends, large families, unfavorable school environment, and audiovisual media showing violent scenes[12]. It is also said that aggressive behavior is caused by negative associations and drug use[13].

The second finding in this study found that the interaction of adolescents with tourists (X2) has a direct negative effect on the tendency of aggressive behavior (Y) of $76.6 \%$ of the adolescents in the Kuta tourist area. This means that variations in the tendency of aggressive behavior are caused by the interaction of adolescents with tourists.

As one of the tourist destinations in Indonesia, Bali is increasingly visited by foreign tourists in addition to the domestic ones. This triggers a high level of interaction between adolescents and tourists. The tourists who come to Bali, of course, bring their own way of life and values. In the opportunity of interaction between tourists with teenagers, the values and lifestyle of each party will unconsciously interact with each other. The area attracts more tourist visits because of its status and points of interests, so the values and patterns of adolescent behavior tend to follow more the values and patterns of the tourists' behavior.

The provision of facilities to support tourism, such as discotheques, karaoke bars, and other night entertainment centers invite aggressiveness among teenagers due to excessive consumption of liquor, the use of nafza, the competition between clubs, so fights/brawls cannot be avoided. Many teenagers die in vain, hacked, tortured, and treated in other forms of crime[14].

We also know that many tourist behavior patterns are classified into problematic behavior, such as the use of narcotics, ecstasy, and sexual deviations, considering the fact that tourists are a group of hedonism (seekers of life satisfaction). There was a process of behavioral internalization through the process of imitation by teenagers associated with this case.

Adolescents are going through a transition phase and are looking for an explorative group to find the various basic life guidelines and values that can be used as a philosophy in their lives. The difficulties in that matter often manifest themselves in their social interaction. The processes of fulfilling the needs and desires often do not run smoothly, so teenagers try to take various shortcuts in order to reach them. They may not approve of these ways in their minds, but they take them anyway in order to fulfill their desires, often ending up in situations that mislead the youngsters and lead to various forms of aggressiveness. Logging on the tourists is inevitable in the area, trajectory, and tourist destinations[15]. In line with the above, it is asserted that many teenagers in Houston are involved in drug trafficking, theft, assault, smuggling, and extortion. All these things begin with emotional tension between the major gangs and the minor ones[16]. This implies that there are often fights between adolescents in the tourist areas in Bali provision due to the competition in the tourism sector.

\section{Conclusions}

Based on the results of the research and the discussion described, it can be concluded that the interaction of peer group (X1) has a negative effect on the tendency of aggressive behavior (Y) in adolescents in the Kuta tourist area. This means that the poor quality of peer group interaction always leads to an aggressive behavior tendency among teenagers in the Kuta tourist area. Besides, the interaction of adolescents with tourists (X2) has a direct negative effect on the tendency of aggressive behavior (Y) in adolescents in Bali's tourist areas. This 
means that the quality of the interaction between teenagers and bad tourists always leads to an aggressive behavior tendency among teenagers in the Kuta tourist area.

\section{References}

[1] B. Krahe, The social psychology of aggression (2nd ed.)., 2nd ed. New York: Psychology Press, (2013).

[2] Mantra Dharmawijaya, "Perihatin Terhadap Kekerasan Remaja," Bali Post, Denpasar, p. 2, (2012).

[3] J. W. Santrock, Life Span Development.(Terjemahan: Benedictine Widyasinta), 2nd ed. Jakarta: Erlangga, (2012).

[4] D. E. Papalia, S. W. Olds, and R. D. Feldman, Human development, 10th ed. New York, NY, US: McGraw-Hill, (2007).

[5] D. Cervone and L. A. Pervin, Personality: Theory and research, 10th ed. (2008).

[6] Roizatul Hasanah, "Pola Pergaulan Remaja di Kawasan Taman Nasional Alas Purwo Banyuwangi (Studi Pada Remaja Dusun Kutorejo, Desa Kalipahit)," Dep. Sociol., (2008).

[7] Irianto, "Dampak Pariwisata Terhadap Kehidupan Sosial Ekonomi Masyarakat di

Gili Trawangan Kecamatan Pemenang Kabupaten Lombok Utara," J. Bisnis dan Kewirausahaan, vol. 7, no. 3, pp. 188-196, (2011).

[8] S. W. Sarwono, Psikologi Remaja. Jakarta: Rajawali Pers, (2011).

[9] J. Cohen, Statistical Power Analysis for The Behavioral Sciences, Second Edi. New York: Lawrence Erlbaum Associates, (1988).

[10] H. S. E. Supono, "Perilaku Agresif Pada Remaja Putri yang Berbeda Status Sosial Ekonomi," (2012).

[11] S. Praptiani, "Pengaruh Kontrol Diri Terhadap Agresivitas Remaja dalam Menghadapi Konflik Sebaya dan Pemaknaan Gender," J. Sains dan Prakt. Psikol., vol. I, no. 1, pp. 1-13, (2013).

[12] Rina, "Faktor- faktor yang Melatarbelakangi Perilaku Agresif Pada Remaja Kelas dua dan tiga SMP Pahlawan Toha Bandung," J. Kesehat. Prima, vol. 3, no. 2, pp. 14-24, (2011).

[13] L. Siddiqah, "Pencegahan dan Penanganan Perilaku Agresif Remaja Melalui Pengelolaan Amarah (Anger Management)," J. Psikol., vol. 37, no. 1, pp. 50-64, (2010).

[14] Anonim, "Mahasiswa Baru Tewas Ditusuk Pria Tidak Dikenal," Bali Post, Bali, p. 3, (2012).

[15] Anonim, “Wisatawan di Kuta Kerap Kecurian,” Bali Post, Kuta, p. 4, (2011).

[16] M. dan Dawkins and C. Gibson, "The Applicability of Agnew's General Theory of Crime and Delinquency to Recent Juvenile Gang Membership in Houston," J. Knowl. Best Pract. Juv. Justice Psychol., vol. 4, no. 1, pp. 5-16, (2006). 